\title{
State and Health (1900-2013): Political Stability and Resources
}

\author{
Carla Leão and Teresa Rodrigues
}

\section{Introduction}

Whroughout the twentieth century, Portugal has undergone major social, political, cultural and economic changes. The same happened in healthcare provision issues, even if the most relevant changes in the way Portuguese governments perceived the need and urgency of a real and effective health policy happened in the mid 1970's. Swiftly Portugal progressed from a narrow understanding of healthcare provision still linked to charitable assistance, to an inclusive approach, based on prevention and on the implementation of other needs, such as the provision of continued care.

In the first decades of the last century, the appearance of Ministries of Health throughout Europe was a sign of a full awareness assigned by the central governments to population's collective health. But in Portugal public health policies do not surpass 60 to 80 years of concerted decision-making, and it is inappropriate to speak of a national health policy before the second half of the century ${ }^{1}$.

In this article we will analyse official legislation to describe the pathway of policymaking in the period 1900-2013, concerning the emergence of the Portuguese Welfare State. In methodological terms, we adopted a descriptive and chronological approach, based on the available national studies on the topic, which allow us to identify different health reforms, and each of their main constraints. Our aim is to answer the following questions: Which was the route of health policy in Portugal, and which was the role performed by the State, as the main actor in this field? How did policy options on public health look like in Portugal, and how might they have influenced morbidity and mortality levels?

The text is divided in two parts. The first systematises the main stages of the Portuguese health policies in the twentieth century, highlighting the relationship between political stability, resources and the State's intervention, strongly related to the emergence of the Welfare State. The second part summarises the milestones of

1 António Correia Campos and Jorge Simões, O percurso da saúde: Portugal na Europa (Coimbra, 2011), p. 65. 
health policy decisions and describes each of them. It starts in 1910, with the establishment of the republic, goes through the military dictatorship and the Estado $N o v o^{2}$, giving a more extensive presentation of changes after the democratic regime and the origins of the Welfare State, embodied in the creation of the National Health Service. It finishes in 2013, emphasising the process of epidemiological transition, the decline of infant mortality rate and the growth of average life expectancy levels. The article ends with major remarks, and the answer to the initial questions.

\section{Part I. Actors and Temporalities}

During the last century, Portugal registered considerable changes in the way collective healthcare and protection in illness were perceived. The legislation between 1910 and 2013 faced several constraints both related to the importance the State gave health and to different political, economic and social contexts of the Purtuguese history.

As in most European countries, the provision of healthcare and support to the poor had its genesis in religious and corporate initiatives. Only progressively did administrative and governmental authorities regard these issues as worthy of a legislative framework and permanent intervention. Until the 18th century, the Portuguese Misericórdias ${ }^{3}$ were the most relevant institutions with regard to collective health, particularly that of the most economically vulnerable. The prominent role of the latter was a consequence of their closeness to the general population and their allocation throughout the country. These two characteristics made them the visible face of the population's support in situations of illness.

National indicators on health, illness and mortality remained stable for centuries, with parasitic and infectious diseases as the major cause of death, high infant mortality rates and low life expectancy, illustrating both the lack of medical knowledge and the slight importance given to health and assistance by the political power. Only in 1901 did a relevant Reform take place, aiming to reorganise public health and regulate public charity. It became the basis of Portuguese public health, inspired by the English model, at that time recognised as the world's most efficient model for hygiene and medical organisation ${ }^{4}$. But until the mid-twentieth century,

2 "New State" in Portuguese. It corresponds to the political dictatorship that ruled the country between 1932 and 1974.

3 Institutions of public utility with religious background, created in the late 15th century in major urban centres and later also in smaller towns and in the Portuguese African colonies. Their human profile and efficiency assured them a high prestige and a major role as providers of care assistance and solidarity. They are still active in Portugal.

4 Jorge Simões, Retrato Político da Saúde. Dependência do Percurso e Inovação em Saúde (Coimbra, 2009), p.26; Ministério da Saúde, História do Serviço Nacional de Saúde, Portal da Saúde. Retrieved from: $\quad$ http://www.min-saude.pt/portal/conteudos $/ \mathrm{a} \% 2 \mathrm{~B}$ saude $\% 2 \mathrm{Bem} \% 2 \mathrm{~B}$ 
the measures adopted in the sphere of healthcare kept an ad hoc character and were mostly concerned with responses to specific episodes. Decision making on matters of health and disease were mostly materialised in situations of national emergency, such as epidemic outbreaks or other humanitarian catastrophes 5 .

In Portugal, the decision-making in healthcare policies was influenced by the way the promotion of health services was seen and performed. Although other actors were involved, such as religious and private charity institutions, the central government maintained the key role, decisively influencing both the articulation of providers, the breadth, and the service's quality. All the legislation sanctioned throughout the last hundred years reflects its influence and main options.

So, when we analyse the evolution of health policies in Portugal for the twentieth century, we must consider the State as the key player, although its role diverges according to the peculiarities and resources in the historical periods identified in Table 1. It depended on three exogenous conditions:

1. the level of political stability;

2. the existence of public financial resources;

3. the intensity of central governmental intervention.

By political stability we mean the existence of the necessary conditions of governance for the design and implementation of health public policies. The existence of public financial resources refers to the State's financial capacity to promote public policies as a priority. The intensity of central governmental intervention concerns its role in health policy design, either when it takes the lead or when it allocates the responsibilities to the private sector. Indeed, if political stability and the existence of financial resources are important conditions in the definition of a health policy, the role that the State assumes towards health defines the healthcare model.

portugal $/$ servico $\% 2$ Bnacional $\% 2 \mathrm{Bde} \% 2 \mathrm{Bsaude} /$ historia $\% 2 \mathrm{Bdo} \% 2 \mathrm{Bsns} /$ historiadosns.htm [Accessed on 23 July 2014].

5 Teresa Rodrigues, "As estruturas populacionais", in José Mattoso, ed., História de Portugal (Lisboa, 1993), p. 127. 
Table 1. Health Policy in Portugal. Attempted periodization (1910-2013)

\begin{tabular}{|c|c|c|c|}
\hline Year & Political stability & $\begin{array}{c}\text { Public financial } \\
\text { resources }\end{array}$ & $\begin{array}{c}\text { Substantial intervention } \\
\text { of State in health policies }\end{array}$ \\
\hline $1910-1926$ & NO & NO & YES \\
\hline $1926-1933$ & NO & NO & NO \\
\hline $1933-1971$ & YES & YES & NO \\
\hline $1971-1995$ & YES & YES & YES \\
\hline $1995-2005$ & YES & NO & NO \\
\hline $2005-2011$ & YES & NO & NO \\
\hline $2011-2013$ & YES & NO & NO \\
\hline
\end{tabular}

Source: Author's elaboration.

\section{Part II. Health as a Major Priority}

In political terms, the first chronological phase corresponds to the historical period called the First Republic (1910-1926), a period of real concern with health issues. Protecting the population's health was taken as a positive symbol by the regime, which tried to create new health institutions with effective intervention. However that permanent aspiration was impossible to achieve, due to political instability, and the scarcity of public funds essential to meet several of the republican promises.

The Constitution of 1911 enshrines the right to public assistance, but not to public health. As in previous times, collective health continued to be understood as the provision of basic medical and healthcare services to the economically disadvantaged groups. In fact, the conceptual distinction concerning health and assistance is assumed by the politically responsible, which made a clear distinction between the right of all the Portuguese population to public health and healthcare, and the assumption of "a duty to aid and care" for the poorest.

At the beginning of the $20^{\text {th }}$ century, the expectations on health sector reform were high. While in opposition, the reformist rhetoric of the Republican Party and the hygienist movement demanded that the new political regime would develop and implement a coherent and effective health policy. In its political program, the government promised all a fraternal society and a healthy lifestyle. So, as one of its main objectives it chose to implement a reform proposed in 1901 by Ricardo Jorge, which represented a significant progress in health care organisation, inspired by the English model ${ }^{6}$. But the assistance proposed in the Constitution was limited,

6 This one was implemented by the Liberal government (1906-1914), and is considered to represent the beginning of the Welfare State. Jorge Fernandes Alves, "Saúde e Fraternidade - A saúde na I República”, in Maria Rita Lino Garnel, ed., Corpo: Estado, medicina e sociedade no tempo 
confined to the standardization and control of medical care and the progressive implementation of primary healthcare. A compulsory social insurance for sickness, disability, and survival allowance ${ }^{7}$ was adopted in May 1919. It reflected a change in the public health model, a wish to expand the population's access to health services and to strengthen the State's role.

The reformist impetus of the First Republic was hampered by the unfavourable economic and financial conjuncture. Nevertheless, some additional positive reforms took place in terms of medical training and public health, such as mandatory vaccination, improved water supply, sanitation, housing conditions and food quality control. By the mid 20's Portugal was a liberal Welfare State, with a "modest social security based on the control of financial and human resources", in a changing relationship between State and citizens. Despite those improvements, no substantial decline of morbidity and mortality took place. The leading causes of death were still infectious and parasitic diseases, infant mortality was persistently high and life expectancy continued to be low ${ }^{10}$.

\section{Choosing Health or Security}

The period 1926-1933 demarcates the military dictatorship, a complex period of financial problems and political instability. The design and implementation of a coherent and sustainable health policy was no longer possible, due to disputes within the regime and to its transience. The few available budgetary resources were used to maintain social order. Ensuring healthcare was one of the least priorities of the military government ${ }^{11}$.

A few months after the military rebellion of 28 May 1926 and the rise of a military dictatorship, the prognosis for public health and collective hygienic conditions was pessimistic. The country faced a "considerable delay, detrimental to the life and

da I República (Lisboa, 2010); Jorge Simões, Retrato Político da Saúde. Dependência do Percurso e Inovação em Saúde (Coimbra, 2009), p.26.

7 Teresa Rodrigues and Carla Leão, "Health in Portugal: actors and temporalities", in Teresa Ferreira Rodrigues and Maria do Rosário Oliveira Martins, eds., Portugal 2031. Ageing and Health Policies, from demographic changes to political options (Lisboa, 2014, forthcoming).

8 Maria Rita Lino Garnel, "Médicos e saúde pública no Parlamento republicano", in Pedro Tavares Almeida and Fernando Catroga, eds., Res Publica: cidadania e representação política em Portugal (Lisboa, 2010).

9 Miriam Halpern Pereira, "As origens do Estado Providência em Portugal: as novas fronteiras entre público e privado", Ler História, 37 (1999), p. 61.

10 Teresa Rodrigues (Coord.), A População Portuguesa. Das longas permanências à conquista da modernidade (Porto, 2008).

11 Fernando Rosas, O Estado Novo (Lisboa, 1994). 
health of citizens, vexing to the national pride" ${ }^{12}$. This a posteriori quotation was a political statement, meant to partially demonize the previous regime, but never the less true.

In this context, some positive arrangements were still made, such as the reorganization of public health services to render local medical authorities a greater autonomy. The central government created the Municipal Boards of Hygiene, designated Sub-inspectors of Health, and local sanitary brigades with the mission of addressing possible disease outbreaks. However, although it was intended to improve the health care system - bringing it to the proximity of populations - this reform did not have the desired effect, since the priorities of the new regime soon focused on the control of public finances ${ }^{13}$.

Some demographic indicators improved, but the main causes of death, infant mortality rate and life expectancy remained the same ${ }^{14}$.

\section{Health and Assistance. The Poor and the Wealthy}

A new stage began with the dictatorial regime known as Estado Novo. For a long period (1933-1971), political stability was ensured. In those decades the central government's inclination to intervene in economic and social affairs was also applicable on healthcare.

With Salazar government ${ }^{15}$, the political and doctrinal conditions in favour of stability were united in order to improve healthcare services. Estado Novo was the golden age of private and religious assistance and healthcare institutions ${ }^{16}$, as it was particularly hostile to the First Republic's health policy, considered to be too centralized. Salazar's position was very clear: Misericórdias regained their leading responsibility for charitable welfare on the basis of ethical criteria.

For the next few decades, a corporative model of society dominated, approved in 1933 , based on a bottom-up system of representation of professional interests controlled by the State, i.e. a corporative vision of health ${ }^{17}$. The model presumed solidarity within each corporation, the upgrading of private public charitable

12 Decree 12477 of 12 October 1926

13 Ibid.

14 Teresa Rodrigues (Coord.), A População Portuguesa. Das longas permanências à conquista da modernidade (Porto, 2008).

15 António de Oliveira Salazar served as Prime Minister of Portugal from 1932 to 1968 . He founded and led the Estado Novo (New State).

16 Rui Manuel Pinto Costa, O poder médico no Estado Novo (1945-1974) (Porto, 2009), p.77; António Correia Campos, Saúde: o custo de um valor sem preço (Lisboa, 1983), p.26.

17 Philippe C. Schmitter, Portugal: do Autoritarismo à Democracia (Lisboa, 1999). 
initiatives under State control, regulation, and partial support ${ }^{18}$. The 1933 Constitution (art.40 and 41) proclaimed the right and obligation of the State to preserve morality, sanitation, nutrition and public hygiene, and to promote and encourage charity, cooperation and mutual aid. It did not include any direct reference to public health, but advocated the need for charitable assistance, which should remain essentially in the hands of private suppliers. Charity prevailed as a traditional form of aid for poor citizens, and the State had only a supplementary intervention and the duty to supervise such institutions.

A Concordat between the Portuguese government and the Catholic Church in 1940 gave to the clerical institution a relevant role in internal affairs and reveals the deliberate choice to incorporate religious institutions in public healthcare, in opposition to the values assumed by the First Republic. In 1944, the basis for the legal organisation of social security was established. The 1998 Act of 15 May confirmed the supplementary nature of the State's action in healthcare provision, and underlined the central role of the Misericórdias. The Portuguese central government was just an intermediator, refusing a direct responsibility in healthcare, the peak of the highly ideological, charitable-corporatist model ${ }^{19}$.

Meanwhile, the Welfare State continued its progress in European democracies. In this international context, profiting from an internal period of relative political freedom, due to the elections of 1945, a new reform on national healthcare took place. The Sanitary Reform of Trigo Negreiros ${ }^{20}$ recognized the weaknesses of individual and corporative health, and advocated an extension of the government's obligations towards its citizens. It distinguished between three levels of intervention: preventive assistance, palliative and curative assistance and constructive assistance. It also deployed State agencies to regulate and supervise sanitary practice, health services and institutions (hospitals, sanatoriums, services related to child and maternal health), and regulated the organisation of particular care institutions. The new hospitals, built by State initiatives were given to the Misericórdias.

The creation of a Federation of Social Security Funds (Caixas de Previdência), allowed the gradual extension of socio-medical services to all citizens, by several independent subsystems of health according to professional activities. But this system continued to exclude a large percentage of the Portuguese population. Still, no universal and comprehensive health service existed, and social inequalities increased, due to each subsystem's lack of efficiency ${ }^{21}$.

18 Rui Manuel Pinto Costa, O poder médico no Estado Novo (1945-1974) (Porto, 2009), p.76.

19 António Correia Campos, Saúde: o custo de um valor sem preço (Lisboa, 1983), p.25.

20 Law Decree 35108 of 7 November 1945.

21 Rui Manuel Pinto Costa, O poder médico no Estado Novo (1945-1974) (Porto, 2009), p.89; Arnaldo Sampaio, Evolução da política de saúde em Portugal depois da Guerra de 1939-K45 e suas consequências. Arquivos do Instituto Nacional de Saúde (Lisboa, 1981), p.27. 
Yet, those measures had a positive effect on health indicators, changing the order of the main causes of death from infectious and parasitic to diseases of the circulatory system $^{22}$. Between 1930 and 1950 the infant mortality rate declined from 143.6 to $98.0 \%$, and the average life expectancy at birth increased from 45 to 55 years ${ }^{23}$.

In 1958, Salazar condescended with public opinion and created the Ministry of Health. It induced a re-evaluation of the health sector, representing a slight change in the design and practice of assistance and health in Portugal ${ }^{24}$, however, with no significant practical consequences.

The 1960s represented a period of economic growth based on the industrialisation and controlled economic liberalisation allowed by the European Free Trade Association (EFTA). In 1961, the colonial war started and social tensions rose, partially as a result of a more wide-spread knowledge about living conditions in other European countries, due to their more elaborated social security systems ${ }^{25}$. Still, the creation and development of health subsystems remained as the regime's official policy, and in 1963 the Social Assistance for Civil State Functionaries (ADSE) was founded.

The State kept the basic principles of its health and assistance policy practically unchanged, but other improvements were outlined. One of the most important acts was a Law on Health Policy and Assistance (1963), which reorganized the Health Base Law of 1944, essentially by removing the charitable character of assistance, and starting a process of centralised health services. However, the supplementary character of the State persisted, as well as its support to private initiative. Thus, barriers to the development of a consistent health policy continued to exist. The health coverage of the country's population progressed slowly, combining actions of private institutions and the State, although the latter was expanding its participation to other sectors, such as local primary health care institutions for maternal and child care.

The Health Ministry gained financial autonomy in the middle of the 1960s, a new awareness on the importance of collective health and the desire to ensure extended intervention by the State. This change was due to the arrival of an elite of technocrats with international experience in public administration ${ }^{26}$. The Portuguese reality was changing, and seizing the new window of opportunity was realised by the rise to

22 Teresa Rodrigues (Coord.), A População Portuguesa. Das longas permanências à conquista da modernidade (Porto, 2008).

23 Teresa Ferreira Rodrigues; Maria João Guardado Moreira, "Modelos de Mortalidade em Portugal", Ler História, 49. (2005)

24 Carlos Farinha dos Santos, "Assistência social” pp. 13-74 in Fernando Rosas and José Maria Brandão Brito, eds., Dicionário da História do Estado Novo (Lisboa, 1996).

25 Rui Manuel Pinto Costa, O poder médico no Estado Novo (1945-1974) (Porto, 2009), p.97.

26 ' António Reis, Portugal Contemporâneo (Lisboa, 1996). 
power of Marcello Caetano ${ }^{27}$. In 1969, Miller Guerra ${ }^{28}$, a former Health Ministry and a political opponent of the regime, argued for the urgent creation and enhancement of the health professional's careers, the establishment of sub-regional hospitals and health centres ${ }^{29}$, the unification of medical health and social action, and the growth of qualified medical and other technical staff. He also underlined the benefits of a ministry that would join healthcare and assistance, and improve the coordination of national healthcare policy, spread between various ministries. These claims would be considered and partially solved with the Reform of Gonçalves Ferreira (1971), and later with the creation of the National Health Service in $1979^{30}$.

Accompanied by the global advances of medical research, these reforms produced positive changes of the Portuguese population's health. Infectious and parasitic diseases were the sixth cause of death in 1970 ( $3 \%$ of all deaths), while circulatory diseases accounted for $39 \%$. The epidemiological transition was on its march ${ }^{31}$. Between 1950 and 1970, the Portuguese infant mortality rate dropped from 98 to $51.3 \%$ and average life expectancy at birth increased from 55 to 65 years ${ }^{32}$.

\section{Health and Democracy. The Welfare State}

In the final years of the Estado Novo, the Reform of 1971 (by Gonçalves Ferreira, State Secretary of Health and Assistance, and the establishment of democracy, the central government kept its dominant role in the definition and implementation of health policy, by developing a network of primary and hospital care, which from 1979 embodies the National Health Service (SNS).

Those were years of stability and ideological and operative continuity regarding public health services, which encompass primary health care services and hospitals closer to the population to which all citizens have access, regardless of their economic

27 Marcello José das Neves Alves Caetano was the last prime minister of the Estado Novo regime, from 1968 until his overthrow in the Carnation Revolution of 1974 . He contributed to less rigid policies in social and health terms.

28 Chairman of Order of Physicians since 1968.

29 Public health services that provide primary health care and are located near the population.

30 Miller Guerra, "Saúde, educação e ciência. Três notas programáticas”, Brotéria, 89: 12 (1969).

31 Teresa Rodrigues (Coord.), A População Portuguesa. Das longas permanências à conquista da modernidade (Porto, 2008).

32 Teresa Ferreira Rodrigues; Maria João Guardado Moreira, "Modelos de Mortalidade em Portugal", Ler História, 49 (2005). 
capacity, employment status or health subsystem. It provided the structural conditions for the emergence and consolidation of the Welfare State ${ }^{33}$.

At the beginning of the 1970s, the outcome was just slightly positive. One of the remaining major problems was the still modest role of the State, and the fact that private health institutions were much more abundant than State-owned ones. Another problem was related to the various health subsystems, and the inefficient management of the existing resources, which maintained social inequalities ${ }^{34}$.

The reform of 1971 was adapted in a context of partial political freedom, and of social claims (such as those of Miller Guerra) ${ }^{35}$. It aimed at the assurance of scientific and technical improvement, effective planning, unification and multidisciplinary in the design and implementation of health policy. It was also meant to guarantee centralized access to health to all Portuguese citizens, innovative in its intentions of coverage and provision ${ }^{36}$. The reform was a turning point, as it attributed to the State the responsibility of coordinating a health policy centralised in its principles, but decentralised in the provision of services, in order to reach the whole population with similar quality and accessibility. The government invested in prevention and proximity, creating the first generation of health centres and Health Posts in small villages. The reform was extremely advanced for its time, in a national, political context, and because it anticipated the creation of a National Healthcare Service, implementing the guidelines of the 1978 International Conference in Alma-Ata. But as expected, it did not definitively disrupt the role of private units providing health services, in particular the coordination between health centres and public and private services dispersed across the country.

The role of the State in the provision of healthcare services increased until 1973, as a result of the international conjuncture that emphasized the government's responsibility to ensure access to primary care to all its citizens. Internally, the government was pressured by public complaints about Portugal's high mortality and morbidity levels. In 1973, the Ministry of Health and Assistance was split, and health

33 António Barreto, "Portugal na periferia do centro: mudança social, 1960 a 1995", Análise Social, 30: 134 (1995); Ana Guillén, Santiago Álvarez and Pedro Adão e Silva "Redesigning the Spanish and Portuguese Welfare States: The Impact of Accession into the European Union", South European Society and Politics, 8 (2003), pp.57-89; José António Pereirinha and Francisco Nunes, "Política social em Portugal e a Europa, 20 anos depois", in António Romão, ed., A Economia portuguesa - 20 anos após a adesão (Coimbra, 2006).

34 Arnaldo Sampaio, "Discurso proferido pelo Dr. Arnaldo Sampaio no acto de posse como Director-geral de Saúde”, O Médico, 54: 1098 (1972), p.518.

35 Law Decree 413/71 of 27 September.

36 Pedro Morais Barbosa, Politica Nacional de Saúde. Arquivos do Instituto Nacional de Saúde (Lisboa, 1972), p.79; Arnaldo Sampaio, Evolução da política de saúde em Portugal depois da Guerra de 1939-45 e suas consequências. Arquivos do Instituto Nacional de Saúde (Lisboa, 1981), p.27. 
became once again an autonomous ministry. Nevertheless, the political opposition disallowed the full realisation of the 1971 Reform objectives ${ }^{37}$.

The Revolution of 25th April 1974 provided a break with the past, also in healthcare issues, by implementing a democratic regime, and abolishing the political impediments which previously barred the extension of universal healthcare. The Programme of the First Provisional Government declares the purpose to create a national health system and gathered both health and social security in the Ministry of Social Affairs. This decision, only apparently contradictory, wanted to assure the effective integration of medical and social services under the same guidance. Simultaneously, a decentralisation on Health provision was tried, in order to offer health care to populations in the smallest villages. The foundation of district administrations and periphery medical service, symbolizes a break with the previous political ideology. In November 1974, the integration of hospitals managed by Misericórdias into public administration was realised ${ }^{38}$.

The democratic Portuguese Constitution of $1976^{39}$ declares (art.64) that health is a universal right carried out by a national universal, comprehensive, and free system. The State should ensure universal access to healthcare, medical and hospital coverage throughout the national territory. Health became a constitutional obligation for the political system. But it did also occupy a prominent place in politics, the fundamental basis of the Portuguese democracy, embraced by several parties and socio-political trends. Indeed, political democratisation become inseparable from social democratisation ${ }^{40}$.

Hence, Portugal recovered the needed political stability to build a real national health system ${ }^{41}$. The Order of 29 July $1978^{42}$, recognized as Arnaut Order (Minister for Social Affairs), anticipates a National Health Service (SNS) that guarantees access to medical and social services to all citizens regardless of their ability to pay. In 1979, the SNS was established ${ }^{43}$, implementing a Welfare State in Portugal inspired by the Beveridge model.

37 Arnaldo Sampaio, Evolução da política de saúde em Portugal depois da Guerra de 1939-45 e suas consequências. Arquivos do Instituto Nacional de Saúde (Lisboa, 1981), p.34.

38 Decree-Law 488/75 of 4 September and Decree-Law 618/75 of 11 November

39 Assembleia da Republica, Constituição de 1976. Retrieved from: http://www.parlamento.pt/Parlamento/Documents/CRP1976.pdf [Accessed on 4 November 2013].

40 Ana Guillén, Santiago Álvarez and Pedro Adão e Silva "Redesigning the Spanish and Portuguese Welfare States: The Impact of Accession into the European Union", South European Society and Politics, 8 (2003), pp.57-89.

41 Carlos Farinha dos Santos, "Assistência social” pp.13-74 in Fernando Rosas and José Maria Brandão Brito, eds., Dicionário da História do Estado Novo (Lisboa, 1996).

42 António Arnaut, Serviço Nacional de Saúde (SNS). 30 Anos de Resistência (Coimbra, 2009).

43 Law 56/79 of 15 September 
Different models could have been adopted to frame the Portuguese National Health Service, but the prevalent political option was to ensure a universal and free SNS, under central governance. The increase of services covering the entire population had a major, positive impact on health indicators in the post-25 April ${ }^{14}$, although it was a slow process and not always linear, implying a strong public investment in terms of human resources, infrastructures and services. Between 1971 and 1995 infectious and parasitic diseases came to represent only $1.5 \%$ of total deaths ${ }^{45}$, infant mortality rate fell from 50 to around $24 \%$, and average life expectancy at birth reached more than 70 years ${ }^{46}$.

Although priority given to health and the development of the SNS differed throughout the 1980s, including some years of public disinvestment between 1980 and $1983^{47}$, measures were taken to deepen the universality of healthcare provided by the State. They focused on autonomy, improvements of the training of health professionals, and decentralisation of services.

In 1983, the Ministry of Health was reopened and the sector got a strengthened structure, particularly for prevention and the regulation of medication. The first aspect is due to the fact that "our country [was] in an advanced stage of transition characterised by the dominance of infectious diseases to the prevalence of the socalled diseases of civilisation", to which primary care should respond accordingly ${ }^{48}$. The second aspect was meant to control both the quality and the prices of the prescript medicines.

Following Portugal's entrance in the European Economic Community (EEC), national economic and financial conditions improved in the mid-1980s. Meanwhile, an international vision of the need for an extended involvement of the private sector

44 The SNS includes integrated healthcare: promotion, surveillance, prevention, diagnosis, treatment, medical and social rehabilitation. It offers primary health care services (community Health Centres), differentiated care (general hospitals, specialty hospitals and other specialized institutions). Possess administrative and financial autonomy had decentralized structure and organization with central, regional and local authorities. António Correia Campos, Saúde: o custo de um valor sem preço (Lisboa, 1983), p.26; Jorge Simões, Retrato Político da Saúde. Dependência do Percurso e Inovação em Saúde (Coimbra, 2009); Paula Santana, "Os ganhos em Saúde e no acesso aos serviços de Saúde: avaliação das últimas três décadas” pp.57-69 in Jorge Simões, ed., Trinta anos do Serviço Nacional de Saúde. Um percurso comentado (Coimbra, 2010).

45 Teresa Rodrigues (Coord.), A População Portuguesa. Das longas permanências à conquista da modernidade (Porto, 2008).

46 Teresa Ferreira Rodrigues; Maria João Guardado Moreira, "Modelos de Mortalidade em Portugal", Ler História, 49. (2005)

47 Jorge Simões and Óscar Domingos Lourenço, "As políticas públicas de Saúde nos últimos 25 anos", in Livro de Homenagem a Augusto Mantas (APES, 2006), p.78.

48 Preamble of the Law Decree 74-C/84 of 2 March. 
in the provision of health care also reached Portugal in the mid-1980s, calling for a larger individual responsibility in the financing and transformation of the SNS ${ }^{49}$.

In the following years several measures were approved to ensure the financial sustainability of the system, such as the introduction of user fees, and other reforms, which aimed to change hospital management to a private business model, in order to reduce public expenditure. The amount of transfers of activities from the public to the private sector was significant. Within OECD, Portugal was spent above average on medication. Nor did an efficient system exist to control the amount and necessity of referral by doctors in primary health care to specialists in the private sector for complementary diagnosis and therapy. Trying to avoid abuses, rational rules on SNS charges were established in $1986^{50}$.

A constitutional revision of 1989 changed the national legal framework, assuming that healthcare should be only "tendentiously free", although safeguarding each citizen economic condition. The 1990 Health Bases ${ }^{51}$ allowed and even encouraged the participation of private entities in the promotion and protection of public health, providing the State with regulatory functions (guidance, planning, evaluation and inspection). Following these amendments, the SNS regulation changed in order to: ensure the regionalisation of management services; promote the development of the private health sector; ensure business management of public health units; and encourage citizens to opt for private health insurances ${ }^{52}$. The new legislative framework intended to promote the integration of primary and hospital care through health facilities, invoking the principle of indivisibility.

In 1993, the Ministry of Health was reorganised, in order to regionalise health policy decisions, allocating powers and reinforcing assignments to five designated regional health authorities. These would ensure the link between local health centres and central hospitals, through integrated healthcare units. Improvements of the implementation of the SNS explain major changes of the leading causes of death ${ }^{53}$, and a continuous decline in mortality and infant mortality rates (the last one from 50 to $6.9 \%$ ). The average life expectancy of the Portuguese population also continued to rise ${ }^{54}$.

49 Jorge Simões, Retrato Político da Saúde. Dependência do Percurso e Inovação em Saúde (Coimbra, 2009), p.98.

50 Decree $57 / 86$ of 20 March

51 Law 48/90 of 24 August

52 Decree $57 / 86$ of 20 March

53 Teresa Rodrigues (Coord.), A População Portuguesa. Das longas permanências à conquista da modernidade (Porto, 2008).

54 Teresa Ferreira Rodrigues; Maria João Guardado Moreira, "Modelos de Mortalidade em Portugal", Ler História, 49. (2005) 


\section{A Time of Difficult Options}

A new phase in health policy began in 1995, characterized by a gradual disengagement of the State, illustrated by the change of management model in public hospitals $s^{55}$. As in other European countries, it was a time of containment, adjustment to economic crises and financially restrained social systems resulting from demographic ageing. It focused on three main topics: re-commercialization, cost reduction and recalibration $^{56}$. Portugal was no exception, and in the second half of the 1990s, the process of adjustment began ${ }^{57}$, worsened by the lack of a welfare system that had been allowed the time to mature. Gradually, adjustment to new realities became inevitable ${ }^{58}$.

Multiple structures were created and new rules were tested. Based on the political and social consensus on urgent needs to strengthen the SNS and to rationalise its management, the measures adopted aimed to achieve such rationalisation without destroying the existing system ${ }^{59}$. Thus, measures were adopted to create a contractual model between payers and providers, to adapt health professional salaries according to their performance, and to modernise public health administration. In 1999 the SNS was restructured, to include regional and local levels of territorial activity. At the regional level, functions of planning, coordination and definition of strategies for technical assistance were assigned to health centres. At the local level, and endowed with a flexible organisation, the population could count on the public health units of local health systems and operative units of public health at the health centres.

At the beginning of the 21 st century, new legislative acts were recommended, among others, permanent and exclusive contracts for physicians, the enlargement of the number of professionals, the regulation of pharmacy and prescriptions, the establishment of public-public partnerships (based on public sector partners), of

55 In 1995 a first experience of private management within a public hospital, through the conclusion of a management agreement with private entities took place concerning the Hospital Fernando da Fonseca in Lisbon surroundings (Amadora-Sintra). Four years later, in 1999, another system at experimental level was adopted close to Oporto (Hospital of São Sebastiāo, in Santa Maria da Feira). In it the management of human resources and acquisitions of goods and services takes place in accordance with private sector practices.

56 Paul Pierson, "Coping with permanent austerity", in Paul Pierson, ed., The new politics of the Welfare (OUP, 2006), p.25.

57 António Barreto, "Mudança social em Portugal, 1960-2000” pp.46-78 in António Costa Pinto, ed., Portugal contemporâneo (Lisboa, 2005).

58 Paul Pierson, "Coping with permanent austerity", in Paul Pierson, ed., The new politics of the Welfare (OUP, 2006); Fernanda Rodrigues, "Assistência social: uma política reticente em tempo de globalização", in Pedro Hespanha and Graça Carapinheiro, eds., Risco social e incerteza: pode o Estado recuar mais? (Porto, 2002); Pedro Adão e Silva, "O Modelo de Welfare da Europa do Sul - Reflexões sobre a utilidade do conceito", Sociologia, Problemas e Práticas, 38 (2002), 76-96.

59 Pedro Pita Barros, As políticas de Saúde em Portugal nos últimos 25 anos: evolução da prestação na década 1987-1996 (Lisboa, 1999). 
public-private partnerships (combining public financing with private capital), and of partnerships within the social sector ${ }^{60}$. With the new political social democratic regime the spirit of the national health system changed. Portugal moved from a model primarily funded through SNS to one where both public and private initiatives coexist.

This change in the design of the national health system caused several discontinuities ${ }^{61}$, such as the public-private partnerships regulated in $2002^{62}$, with the hospital enterprise management models implementation (EPE) ${ }^{63}$ sensitive to expenditure and committed to reward merit. Equally, the decision to establish the National Network of Continuing Care ${ }^{64}$, comprising public, private and social entities, thus fulfilling the growing need of reassuring healthcare and maintaining the quality of life of citizens in a context of demographic ageing, changes of the family structure and other social transitions. The network was rebuilt in 2006 under the name of National Network of Integrated Continued Care (RNCCI) ${ }^{65}$, taking advantage of EU funds to finance its execution, and to include palliative care. During a growing diversification of social and private operators participating in the SNS, the Portuguese Health Regulation Authority (ERS) was created ${ }^{66}$

The need to adapt health services to a rapidly changing demographic structure had already influenced the design of various health policy plans in this period, as the 20042010 National Health Plan, the National Programme for the Health of Elderly People, or the National Palliative Care Programme ${ }^{67}$. The obligation to find a solution for the long surgery waiting lists, also led to the creation of an Integrated Surgery for Subscribers Management System (SIGIC). Its purpose was to ensure that surgical treatment occurs within a minimum set time, and reduce the number of patients waiting for surgery at SNS establishments ${ }^{68}$.

In 2005 the epidemiological, sanitary and demographic transition was concluded when infectious and parasitic diseases disappeared among the leading causes of

60 Resolution of the Council of Ministers 162/2001, of 16 November

61 Pedro Pita Barros, Análises da saúde (Lisboa, 2007), p.115.

62 With the first proposals thrown in 2003 and some completed in 2014, only hospitals (Loures, Braga, Cascais and Vila Franca de Xira). Decree-Law 185/2002 of 20 August.

63 Law 27/2002 of 8 November

64 Decree-Law 281/2003 of 8 November

65 Decree-Law 101/2006 of 6 June

66 Decree-Law 309/2003 of 10 December

67 Suzete Gonçalves, "Cuidados Continuados Integrados” pp.23-47 in Jorge Simões, ed., Trinta anos do Serviço Nacional De Saúde. Um Percurso Comentado (Coimbra, 2011).

68 Council of Ministers Resolution 79/2004 of 3 June 
death $^{69}$, infant mortality rate was low $(3.5 \%$ ) and average life expectancy at birth had increased up to 78 years $^{70}$.

\section{Reorganization and Sustainability}

The deterioration of Portugal's economic and financial crisis led to the Restructuring Programme for Central Administration (PRACE) ${ }^{71}$ implemented in 2005. It aimed to reduce costs and enable economies of scale, without compromising specialisation, quality, and executive autonomy of hospitals and local Health Centres ${ }^{72}$. The DecreeLaw 200/2006 of 25 October established the procedures for the extinction, fusion, and restructuring of services and reduction of human resources.

PRACE tried to rationalize the SNS through a multitude of adjustments, such as the closure of health services in smaller places, the fusion of hospitals and health centres, and the rearrangement of health units with management functions. User's fees were revised and increased after 2007, to guarantee SNS sustainability. Health administrators were required by the government to produce plans to reduce costs ${ }^{73}$, and health investment was interrupted with two exceptions: the National Network of Integrated Continued Care and primary care programs. In fact, the Lisbon Treaty $(2007)^{74}$, and the International Health Regulations (2005) $)^{75}$ made national decision makers adapt a new definition of the emergency network and hospital emergencies, the definition and improvement of surveillance, alert and response mechanisms, and the intensification in primary care.

In 2009, another restructuring of health services took place, in order to provide better operational services, a technical and flexible organisational model, and to ensure a swift and effective protection of the collective health ${ }^{76}$. This procedure included two levels of activity: regional and local surveillance and health monitoring based on a comprehensive epidemiologic perspective, health planning and strategies.

Portuguese health professionals had excellent competencies, and high qualitative standards in the provision of health care were guaranteed. However, a shortage of human resources, particularly doctors was eminent, explaining the increase of

69 Teresa Rodrigues (Coord.), A População Portuguesa. Das longas permanências à conquista da modernidade (Porto, 2008).

70 Teresa Ferreira Rodrigues; Maria João Guardado Moreira, "Modelos de Mortalidade em Portugal”, Ler História, 49. (2005)

71 Council of Ministers Resolution 124/2005 of 4 August

72 António Correia Campos, Reformas da saúde: o fio condutor (Coimbra, 2008), p.42.

73 Order 10760/2010 of 29 de June.

74 Title XIV Art.168 (Assunção Esteves; Noémia Pizarro, O Tratado de Lisboa (Chamusca 2008).

75 Notice 12/2008 of 23 January.

76 Decree-Law 81/2009 of 2 April. 
numerus clausus in medicine and nursery graduations and legislation that allowed retired doctors to continue to practise (2010).

The shortage of human resources caused extensive waiting times for consultations and treatments. The problem had already been perceived in 2004 by the Integrated Surgery for Subscribers Management System (SIGIC) as a response. It was improved four years later, by extension to private entities contracted with the SNS. Two other measures (Law 41/2007 of 24 August, and Ministerial Ordinance 615/2008 of 11 July) improved and regulated the maximum guaranteed response times to all kinds of health care benefits (e.g. Health Centres care, home care, hospital care, diagnostic and therapeutic care and programmed surgeries), and regulated the integrated system of transfer and management access to the first hospital specialty consultation on SNS institutions, known as Consultation on Time, in order to ensure maximum terms of response, according to clinical priorities.

The evaluation made by the World Health Organisation on the implementation of the 2004-2010 National Health Plan was largely positive, but underlined the need to achieve the goals set out in the 2011-2016 National Health Plan in what concerns equity in access and quality of health services ${ }^{77}$. Although the purchase of goods, services and other activities involving public expenditure were reduced to their lower levels, those years stood as a period of positive demographic trends.In 2010, infant mortality rate had been reduced to a minimum level of $2.5 \%$, average life expectancy at birth had increased to 80 years. The epidemiological transition was definitely over $^{78}$.

\section{Crisis, Sustainability, Reforms and Reductions}

The last phase until the present date can be defined by words like "crisis", "restructuring", "sustainability of the SNS" and "reductions". It has also been a period of the State's disinvestment in health and of the civil society's dissatisfaction.

The autonomy of the Portuguese government was restricted after the signature of the Memorandum of Understanding, in July 2011, and the approval of PREMAC (Reduction and Improvement Program of State's Central Administration), with the aim of restructuring and reducing expenses, closures, fusion and restructuration of organizations and services and rationalization of human resources. The Decree-Law 124/2011 of 29 December presents the Health Program.

77 Ministério da Saúde, História do Serviço Nacional de Saúde, Portal da Saúde. Retrieved from: http://www.min-saude.pt/portal/conteudos/a\%2Bsaude $\% 2 \mathrm{Bem} \% 2 \mathrm{~B}$ portugal $/$ servico $\% 2$ Bnacional $\% 2 \mathrm{Bde} \% 2 \mathrm{Bsaude} /$ historia $\% 2 \mathrm{Bdo} \% 2 \mathrm{Bsns} /$ historiadosns.htm [Accessed in 23 July 2014].

78 Teresa Rodrigues (Coord.), A População Portuguesa. Das longas permanências à conquista da modernidade (Porto, 2008). 
Restrictive decisions predominate, although less pronounced in primary and in palliative care. A thorough restructuring of departments and organizations took place within the SNS and the Ministry of Health. The amount of health services and human resources was reduced and mega-health-units were created by merging/grouping Health Centres and hospitals. There was also an increase in healthcare costs for users, at a time when individual earnings were decreasing ${ }^{79}$. The recruitment of health professionals diminished, the number of working hours increased $^{80}$ with no increase in salary, and the prescription of Complementary Diagnostic Exams and Therapies became more difficult ${ }^{81}$. In primary care (health centres), the design of local health support changed ${ }^{82}$, reducing the number of Groups of Health Centres (ACES) and abolishing the rule that previously limited the number of users to a maximum of 200,000. For inhabitants in smaller places in the interior, rural areas, distances to health services increased.

State budgets for 2012 and 2013 show widespread contention concerning the size of human resources, remuneration, and career progression. In May 2013, the final version of the new 2012-2016 National Health $\operatorname{Plan}^{83}$, was published. It meant to be the "foundation for the health system of the $21^{\text {st }}$ Century", intending to solve system problems, particularly those identified by WHO when evaluating the previous plan.

In October 2013, the articulation procedures between the institutions and services of the SNS and private institutions of social solidarity were defined. However, in a context of economic constraint, fusion and concentration of health services, this legislative document may produce some uncertainties, whilst at the same time representing a return to the trend initiated with democracy.

From 2010 until 2013 curious patterns emerged in Portugal, such as the increase of mortality caused by malignant tumors and of respiratory system diseases ${ }^{84}$. Since prevention and proximity to health services are very important in curbing the effects of these pathologies, might we interpret those negative trends as a consequence of the worsening of healthcare conditions, and the disinvestment in health? Simultaneously, the Portuguese life expectancy at birth stagnated at about 80 years and infant mortality increased to $2.9 \% 0^{85}$.

79 Council of Ministers Resolution 22/2012 of 9 March

80 Law 68/2013 of 29 August

81 Order $10430 / 2011$ of 18 August

82 Ministerial Ordinance 394-A/2012 of 29 November

83 Direção-Geral de Saúde, Plano Nacional de Saúde 2012-2016. Retrieved from: http://pns.dgs.pt/pns-versao-completa [Accessed on 23 July 2014].

84 PORDATA. Available in: http://www.pordata.pt/

85 Idem. 


\section{Conclusions}

In the previous pages we have described the most important political measures with regard to public health and assistance in Portugal, from the beginning of the twentieth century until the present day (2013). For each different phase, we made a final observation, about the contemporary epidemiological pattern, the infant mortality rate and the average life expectancy, indicating the potential influence of political decision making on health and the demographic pattern.

Portugal's journey went from healthcare provision linked to charitable assistance and mainly provided by private institutions, to a universal approach, with the main role played by public health services. On the way, a Welfare State and SNS developed, ending in a model where private and social institutions, such as the Misericordia, again have achieved an increasingly important role.

The strong links between political stability, resources and the Welfare State have been demonstrated. From 1900 to 2013, health policies were only indirectly affected by the sequence of political regimes and ideologies in power. In the long time perspective, there has been a growing interest and importance given by the central powers to healthcare and public health policies, with only two exceptions: in the Estado Novo 1926-1970 and during the economic crisis 2007-2013.

Over the years, the topic of health gained importance, and during all those years the State kept its key role in all health related issues and decisions, hence being the responsible for the final contributions to the Portuguese demographic and sanitarian conditions.

We have showed that the major turning point happened during the implementation of the SNS in the 1970's when central government adopted healthcare as a priority and a duty towards its voters. Thus, the Portuguese epidemiological transition became possible, with the drastic decline of infant mortality and the increase in average life expectancy during a record time of 31 years, putting Portugal in a privileged position within the European Union and the World. Despite of these improvements, Portugal is today a country with great constraints in the healthcare sector, parallel to a successive growth of a dominating private and social sector.

But what lessons can be drawn from these policy decisions for the future of Portuguese public health? The future remains incognita ...

Carla Leão is a PhD student and invited teacher at the Department of Political Studies in Universidade NOVA de Lisboa, Portugal. She is a researcher of CEPESECentro de Estudos de População, Economia e Sociedade - Universidade do Porto.

Teresa Rodrigues is Professor of International Relations at the Department of Political Studies, Universidade NOVA de Lisboa, Portugal. She is a member of the 
board of IPRI - Instituto Português de Relaçōes Internacionais (NOVA) and a researcher of CEPESE- Centro de Estudos de População, Economia e Sociedade Universidade do Porto

\section{Acknowledgements}

This work was co-funded by FEDER funds through the Operational Program for Competitiveness Factors - COMPETE and by National funds through FCT Fundação para a Ciência e a Tecnologia as part of the project Ageing and Health in Portugal. Policies and Practices, FCOMP-01-0124-FEDER-PTDC/CSDEM/109967/2009. 


\section{References}

Alves, Jorge Fernandes, "Saúde e Fraternidade - A saúde na I República”, in Maria Rita Lino Garnel, ed., Corpo: Estado, medicina e sociedade no tempo da I República (Lisboa, 2010).

Arnaut, António, Serviço Nacional de Saúde (SNS). 30 Anos de Resistência (Coimbra, 2009).

Assembleia da Republica, Constituição de 21 de Agosto de 1911. Retrieved from: http://debates.parlamento.pt/Constituicoes_PDF/CRP-1911.pdf [Accessed on November 2013].

Assembleia da Republica, Constituição da República Portuguesa, 1933. Retrieved from: http://www.parlamento.pt/Parlamento/Documents/CRP-1933.pdf [Accessed on November 2013].

Assembleia da Republica, Constituição de 1976. Retrieved from: http://www.parlamento.pt/Parlamento/Documents/CRP1976.pdf [Accessed on November 2013].

Barbosa, Pedro Morais, Política Nacional de Saúde. Arquivos do Instituto Nacional de Saúde (Lisboa, 1972).

Barreto, António "Portugal na periferia do centro: mudança social, 1960 a 1995", Análise Social, 30: 134 (1995).

Barreto, António, "Mudança social em Portugal, 1960-2000" pp.46-78 in António Costa Pinto, ed., Portugal contemporâneo (Lisboa, 2005).

Barros, Pedro Pita, As políticas de Saúde em Portugal nos últimos 25 anos: evolução da prestação na década 1987 - 1996 (Lisboa, 1999).

Barros, Pedro Pita, Análises da saúde (Lisboa, 2007).

Campos, António Correia, Saúde: o custo de um valor sem preço (Lisboa, 1983).

Campos, António Correia, Reformas da saúde: o fio condutor (Coimbra, 2008).

Campos, António Correia and Jorge Simōes, O percurso da saúde: Portugal na Europa (Coimbra, 2011).

Costa, Rui Manuel Pinto, O poder médico no Estado Novo (1945-1974) (Porto, 2009). Esteves, Assunção; Pizarro, Noémia, O Tratado de Lisboa (Chamusca 2008)

European Union, Tratado de Lisboa. Jornal Oficial da União Europeia (2007), C 306. Retrived from: http://eur-lex.europa.eu/legalcontent/PT/TXT/PDF/?uri=OJ:C:2007:306:FULLandfrom=EN [Accessed on September 2012].

Direção-Geral de Saúde, Plano Nacional de Saúde 2012-2016. Retrieved from: http://pns.dgs.pt/pns-versao-completa [Accessed on July 2014].

Garnel, Maria Rita Lino, "Médicos e saúde pública no Parlamento republicano", in Pedro Tavares Almeida and Fernando Catroga, eds., Res Publica: cidadania e representação política em Portugal (Lisboa, 2010). 
Gonçalves, Suzete, "Cuidados Continuados Integrados" pp.23-47 in Jorge Simões, ed., Trinta anos do Serviço Nacional De Saúde. Um Percurso Comentado (Coimbra, 2011).

Guerra, Miller, "Saúde, educação e ciência. Três notas programáticas", Brotéria, 89: 12 (1969).

Guillén, Ana, Santiago Álvarez and Pedro Adão e Silva "Redesigning the Spanish and Portuguese Welfare States: The Impact of Accession into the European Union", South European Society and Politics, 8 (2003), 57-89.

Lopes, Octávio Gonçalves, "Planeamento em saúde, para a história da evolução das estruturas de saúde em Portugal”, Revista Crítica de Ciências Sociais, 23 (1987), 360.

Ministério da Saúde, História do Serviço Nacional de Saúde, Portal da Saúde. Retrieved from: http://www.minsaude.pt/portal/conteudos/a $\% 2 \mathrm{Bsaude} \% 2 \mathrm{Bem} \% 2 \mathrm{Bportugal} /$ servico $\% 2 \mathrm{Bnacio}$ nal $\% 2 \mathrm{Bde} \% 2 \mathrm{Bsaude} /$ historia $\% 2 \mathrm{Bdo} \% 2 \mathrm{Bsns} /$ historiadosns.htm [Accessed in July 2014].

Pereira, Miriam Halpern, "As origens do Estado Providência em Portugal: as novas fronteiras entre público e privado”, Ler História, 37 (1999).

Pereirinha, José António and Francisco Nunes, "Política social em Portugal e a Europa, 20 anos depois", in António Romão, ed., A Economia portuguesa - 20 anos após a adesão (Coimbra, 2006).

Pierson, Paul "Coping with permanent austerity", in Paul Pierson, ed., The new politics of the Welfare (OUP, 2006).

Reis, António, Portugal Contemporâneo (Lisboa, 1996).

Rodrigues, Fernanda "Assistência social: uma política reticente em tempo de globalização", in Pedro Hespanha and Graça Carapinheiro, eds., Risco social e incerteza: pode o Estado recuar mais? (Porto, 2002).

Rodrigues, Teresa (Coord.), A População Portuguesa. Das longas permanências à conquista da modernidade (Porto, 2008).

Rodrigues, Teresa and Carla Leão, "Health in Portugal: actors and temporalities" in Teresa Ferreira Rodrigues and Maria do Rosário Oliveira Martins, eds., Portugal 2031. Ageing and Health Policies, from demographic changes to political options (Lisboa, 2014, forthcoming).

Rodrigues, Teresa Ferreira, "As estruturas populacionais", in José Mattoso, ed., História de Portugal (Lisboa, 1993).

Rodrigues, Teresa Ferreira; Moreira, Maria João Guardado, "Modelos de Mortalidade em Portugal", Ler História, 49. (2005)

Rosas, Fernando, O Estado Novo (Lisboa, 1994).

Sampaio, Arnaldo, "Discurso proferido pelo Dr. Arnaldo Sampaio no acto de posse como Director-geral de Saúde”, O Médico, 54: 1098 (1972). 
Sampaio, Arnaldo, Evolução da politica de saúde em Portugal depois da Guerra de 193945 e suas consequências. Arquivos do Instituto Nacional de Saúde (Lisboa, 1981). Santana, Paula, "Os ganhos em Saúde e no acesso aos serviços de Saúde: avaliação das últimas três décadas" pp. 57-69 in Jorge Simões, ed., Trinta anos do Serviço Nacional de Saúde. Um percurso comentado (Coimbra, 2010).

Santos, Carlos Farinha, "Assistência social" pp. 13-74 in Fernando Rosas and José Maria Brandão Brito, eds., Dicionário da História do Estado Novo (Lisboa, 1996).

Schmitter, Philippe C., Portugal: do Autoritarismo à Democracia (Lisboa, 1999).

Silva, Pedro Adão, "O Modelo de Welfare da Europa do Sul - Reflexōes sobre a utilidade do conceito", Sociologia, Problemas e Práticas, 38 (2002), 76-96.

Simōes, Jorge, Retrato Político da Saúde. Dependência do Percurso e Inovação em Saúde (Coimbra, 2009).

Simões, Jorge and Óscar Domingos Lourenço, "As políticas públicas de Saúde nos últimos 25 anos", in Livro de Homenagem a Augusto Mantas (APES, 2006).

\section{Legislation}

Diário da República, Decree 12477 of 12 October 1926, Ministério da Instrução Pública - Direcção Geral de Saúde. Retrieved from: http://dre.pt/pdfgratis/1926/10/22700.pdf [Accessed on 7 September 2013].

Diário da República, Law 1998 of 15 May 1944, Ministério do Interior. Retrieved from: https://dre.pt/pdf1sdip/1944/05/10200/04330437.pdf [Accessed on October 2013].

Diário da República, Decree-Law 35108 of 7 November 1945, Ministério do Interior - Sub-Secretariado de Estado da Assistência Social. Retrieved from: https://dre.pt/pdf1sdip/1945/11/24700/08990922.pdf [Accessed on October 2013].

Diário da República, Law 2011/46 of 2 April 1946, Presidência da República Secretaria. Retrieved from:

https://dre.pt/pdf1sdip/1946/04/07000/02010204.pdf [Accessed on October 2013].

Diário da República, Law 2120/63 of 19 July 1963, Presidência da República. Retrieved from: https://dre.pt/pdf1sdip/1963/07/16900/09690973.pdf [Accessed on October 2013].

Diário da República, Decree-Law 413/71 of 27 of September 1971, Ministério da Saúde e Assistência. Retrieved from:

http://dre.pt/pdf1sdip/1971/09/22800/14061434.pdf_[Accessed on March 2011]. 
Diário da República, Decree-Law $414 / 71$ of 27 of September 1971, Ministério da Saúde e Assistência. Retrieved from:

http://dre.pt/pdf1sdip/1971/09/22800/14061434.pdf_Accessed on March 2011].

Diário da República, Decree-Law 488/75 of 4 September 1975, Ministério dos Assuntos Sociais. Retrieved from:

http://dre.pt/pdf1sdip/1975/09/20400/13051306.pdf [Accessed on December 2012]

Diário da República, Decree-Law 618/75 of 11 November 1975, Ministério dos Assuntos Sociais. Retrieved from:

https://dre.pt/pdf1sdip/1975/11/26100/17881788.pdf [Accessed on December 2012]

Diário da República, Decree-Law $17 / 77$ of 12 January 1977, Ministério dos Assuntos Sociais. Retrieved from:

http://www.dre.pt/pdf1s/1977/01/00900/00580060.pdf [Accessed on October 2013].

Diário da República, Decree 12/77 of 7 February 1977, Ministério dos Assuntos Sociais. Retrieved from:

http://www.dre.pt/pdf1s/1977/02/03101/00010003.pdf[Accessed on August 2012].

Diário da República, Law 56/79 of 15 September 1979, Assembleia da República. Retrieved from: http://dre.pt/pdf1sdip/1979/09/21400/23572363.pdf [Accessed on December 2009].

Diário da República, Decree-Law of 254/82 of 29 June 1982, Ministério dos Assuntos Sociais. Retrieved from: http://dre.pt/pdf1sdip/1982/06/14700/18971900.pdf [Accessed on January 2012].

Diário da República, Decree 97/83 of 22 April 1983, Ministério dos Assuntos Sociais - Secretaria de Estado da Saúde - Gabinete do Secretário de Estado. Retrieved from: https://dre.pt/pdf1sdip/1983/04/09300/14391453.pdf [Accessed on September 2010].

Diário da República, Decree-Law 344-A/83 of 25 July 1983, Presidência do Conselho de Ministros. Retrieved from

http://dre.pt/pdf1sdip/1983/07/16901/00010007.pdf [Accessed on September 2010].

Diário da República, Decree-Law 74-C/84 of 2 March 1984, Presidência do Conselho de Ministros e Ministérios das Finanças e do Plano e da Saúde. Retrieved from: https://dre.pt/pdf1sdip/1984/03/05302/00050022.pdf [Accessed on January 2012]. 
Diário da República, Decree-Law 68/84 of 27 February 1984, Presidência do Conselho de Ministros e Ministérios das Finanças e do Plano e da Saúde. Retrieved from: http://dre.pt/pdf1sdip/1984/02/04900/06540656.pdf [Accessed on January 2012].

Diário da República, Decree-Law 103-A/84 of 30 March 1984, Presidência do Conselho de Ministros e Ministérios das Finanças e do Plano, da Saúde, da Indústria e Energia e do Comércio e Turismo. Suplemento. Retrieved from https://dre.pt/pdf1sdip/1984/03/07601/00010010.pdf; 2o Suplemento. Retrieved from https://dre.pt/pdf1sdip/1984/03/07602/00170026.pdf [Accessed on January 2012].

Diário da República, Decree-Law 57/86 of 20March 1986, Ministério da Saúde. Retrieved from: http://dre.pt/pdf1sdip/1986/03/06600/06690671.pdf [Accessed on January 2012].

Diário da República, Decree-Law 19/88 of 21 January 1988, Ministério da Saúde. Retrieved from https://dre.pt/pdf1sdip/1988/01/01703/00200023.pdf [Accessed on January 2012].

Diário da República, Constitutional Law 1/89 of 8 July 1989, Assembleia da República. Retrieved from:

https://dre.pt/pdf1sdip/1989/07/15501/00020069.pdf [Accessed on January 2012].

Diário da República, Law $48 / 90$ of 24 August 1990, Assembleia da República. Retrieved from: http://dre.pt/pdf1sdip/1990/08/19500/34523459.pdf [Accessed on January 2012].

Diário da República, Decree-Law $11 / 93$ of 15 January 1993, Ministério da Saúde. Retrieved from: http://dre.pt/pdf1sdip/1993/01/012A00/01290134.pdf [Accessed on May 2010].

Diário da República, Decree-Law $117 / 98$ of 5 May 1998, Ministério da Saúde. Retrieved from: https://dre.pt/pdf1sdip/1998/05/103A00/19911995.pdf [Accessed on September 2010].

Diário da República, Decree-Law 151/98 of 5 June 1998, Ministério da Saúde. Retrieved from: http://www.dre.pt/pdf1s/1998/06/130A00/25622569.pdf [Accessed on January 2010].

Diário da República, Decree-Law $286 / 99$ of 27 April 1999, Ministério da Saúde. Retrieved from: http://dre.pt/pdf1sdip/1999/07/173A00/46904695.pdf [Accessed on January 2010].

Diário da República, Decree-Law $157 / 99$ of 10 May 1999, Ministério da Saúde. Retrieved from: http://dre.pt/pdf1sdip/1999/05/108A00/24242435.pdf [Accessed on January 2010]. 
Diário da República, Resolution of the Council of Ministers 162/2001 of 16 November 2001, Presidência do Conselho de Ministros. Retrieved from: https://dre.pt/pdf1sdip/2001/11/266B00/73387339.pdf [Accessed on October 2009].

Diário da República, Decree-Law 185/2002 of 20 August 2002, Ministério da Saúde. Retrieved from: http://dre.pt/pdf1sdip/2002/08/191A00/58525859.pdf [Accessed on February 2010].

Diário da República, Law 27/2002 of 8 November 2002, Assembleia da República. Retrieved from: http://dre.pt/pdf1sdip/2002/11/258A00/71507154.pdf [Accessed on January 2010].

Diário da República, Decree-Law 60/2003 of 1 April 2003, Ministério da Saúde. Retrieved from: http://dre.pt/pdf1sdip/2003/04/077A00/21182127.pdf [Accessed on March 2010].

Diário da República, Decree-Law 281/2003 of 8 November 2003, Ministério da Saúde. Retrieved from:

http://dre.pt/pdf1sdip/2003/11/259A00/74927499.pdf [Accessed November 2009].

Diário da República, Decree-Law 309/2003 of 10 December 2003, Ministério da Saúde. Retrieved from:

http://dre.pt/pdf1sdip/2003/12/284A00/83298338.pdf [Accessed on December 2009].

Diário da República, Council of Ministers Resolution 79/2004 of 3 June 2004, Presidência do Conselho de Ministros. Retrieved from: https://dre.pt/pdf1sdip/2004/06/147B00/38463848.pdf [Accessed on June 2010].

Diário da República, Decree-Law 88/2005 of 3 June 2005, Ministério da Saúde. Retrieved from: http://dre.pt/pdf1sdip/2005/06/107A00/36063606.pdf [Accessed on February 2011].

Diário da República, Council of Ministers Resolution 124/2005 of 4 August 2005, Presidência do Conselho de Ministros. Retrieved from: http://dre.pt/pdf1sdip/2005/08/149B00/45024504.pdf [Accessed on May 2010].

Diário da República, Council of Ministers Resolution 157/2005 of 12 October 2005. Retrieved from: https://dre.pt/pdf1s/2005/10/196B00/59815982.pdf [Accessed on August 2012].

Diário da República, Normative Order 30/2006 of 31 March 2006, Ministério do Trabalho e da Solidariedade Social. Retrieved from: https://dre.pt/pdf1sdip/2006/05/088B00/32593259.pdf [Accessed on November 2013]. 
Diário da República, Decree-Law 101/2006 of 6 June 2006, Ministério da Saúde. Retrieved from: http://dre.pt/pdf1s/2006/06/109A00/38563865.pdf [Accessed on October 2010].

Diário da República, Decree-Law no 200/2006 of 25 October 2006, Ministério das Finanças e da Administração Pública. Retrieved from: https://dre.pt/pdf1sdip/2006/10/20600/73897393.pdf [Accessed on May 2010]. Diário da República, Decree-Law 212/2006 of 27 October 2006, Ministério da Saúde. Retrieved from: http://dre.pt/pdf1sdip/2006/10/20800/75177525.pdf [Accessed on May 2010].

Diário da República, Decree-Law 298/2007 of 22 June 2007, Ministério da Saúde. Retrieved from: http://www.dre.pt/pdf1s/2007/08/16100/0558705596.pdf [Accessed on August 2012].

Diário da República, Law 31/2007 of 10 August 2007, Grandes Opções do Plano para 2008. Retrieved from:

http://www.dre.pt/pdf1s/2007/08/15400/0512705181.pdf_[Accessed on November 2013].

Diário da República, Law 41/2007 of 24 August 2007, Assembleia da República. Retrieved from: http://dre.pt/pdf1sdip/2007/08/16300/0566405665.pdf [Accessed on January 2012].

Diário da República, Notice 12/2008 of 23 January 2008, Ministério dos Negócios Estrangeiros. Retrieved from:

http://dre.pt/pdf1sdip/2008/01/01600/0063800687.pdf [Accessed on February 2013].

Diário da República, Decree-Law 28/2008 of 22 February 2008, Ministério da Saúde. Retrieved from: http://dre.pt/pdf1sdip/2008/02/03800/0118201189.pdf [Accessed on February 2012].

Diário da República, Ministerial Ordinance 615/2008 of 11 July 2008, Ministério da Saúde. Retrieved from:

http://dre.pt/pdf1sdip/2008/07/13300/0440804414.pdf [Accessed on April 2012].

Diário da República, Decree-Law 81/2009 of 2 April 2009, Ministério da Saúde. Retrieved from: http://dre.pt/pdf1sdip/2009/04/06500/0205802062.pdf [Accessed on June 2013].

Diário da República, Ministerial Ruling 14223/2009 of 24 June 2009, Ministério da Saúde. Retrieved from

https://dre.pt/pdf2sdip/2009/06/120000000/2466724669.pdf[Accessed on June 2013].

Diário da República, Order 10760/2010 of 29 de June 2010, Ministérios das Finanças e da Administração Pública e da Saúde. Retrieved from http://dre.pt/pdf2sdip/2010/06/124000000/3545035450.pdf [Accessed on June 2013]. 
Diário da República, Order 10430/2011 of 18 August 2011, Ministério da Saúde Gabinete do Secretário de Estado da Saúde. Retrieved from: https://dre.pt/pdf2sdip/2011/08/158000000/3387133871.pdf [Accessed on January 2013].

Diário da República, Decree-Law 124/2011 of 29 de December 2011, Ministérios da Saúde. Retrieved from:

https://dre.pt/pdf1sdip/2011/12/24900/0549105498.pdf [Accessed on January 2013].

Diário da República, Council of Ministers Resolution 22/2012 of 9 March 2012, Presidência do Conselho de Ministros. Retrieved from: https://dre.pt/pdf1sdip/2012/03/05000/0106301064.pdf [Accessed on January 2013].

Diário da República, Ministerial Ordinance 394-A/2012 of 29 November 2012, Presidência do Conselho de Ministros e Ministérios das Finanças e da Saúde. Retrieved from: https://dre.pt/pdf1sdip/2012/11/23101/0000200005.pdf [Accessed on January 2013].

Diário da República, Law 68/2013 of 29 August 2013, Ministério da Saúde. Retrieved from: https://dre.pt/application/file/499440 [Accessed on February 2014].

Diário da República, Decree-Law 138/2013 of 9 October 2013, Ministério da Saúde. Retrieved from: https://dre.pt/pdf1sdip/2013/10/19500/0606806071.pdf [Accessed on February 2014]. 